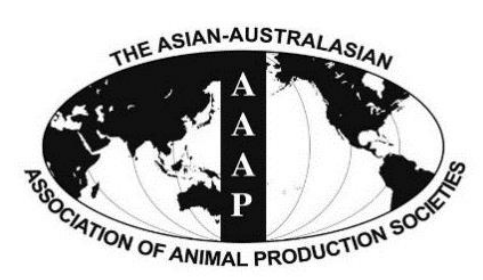

\title{
Association of Chicken Growth Hormones and Insulin-like Growth Factor Gene Polymorphisms with Growth Performance and Carcass Traits in Thai Broilers
}

\author{
Nguyen Thi Lan Anh ${ }^{1}$, Sajee Kunhareang ${ }^{1,2}$, and Monchai Duangjinda ${ }^{1,2, *}$ \\ ${ }^{1}$ Department of Animal Science, Faculty of Agriculture, Khon Kaen University, Khon Kaen 40002, Thailand
}

\begin{abstract}
Molecular marker selection has been an acceptable tool in the acceleration of the genetic response of desired traits to improve production performance in chickens. The crossbreds from commercial parent stock (PS) broilers with four Thai synthetic breeds; Kaen Thong (KT), Khai Mook Esarn (KM), Soi Nin (SN), and Soi Pet (SP) were used to study the association among chicken growth hormones $(c G H)$ and the insulin-like growth factor $(I G F-I)$ genes for growth and carcass traits; for the purpose of developing a suitable terminal breeding program for Thai broilers. A total of 408 chickens of four Thai broiler lines were genotyped, using polymerase chain reaction-restriction fragment length polymorphism methods. The $c G H$ gene was significantly associated with body weight at hatching; at 4, 6, 8, 10 weeks of age and with average daily gain (ADG); during 2 to 4, 4 to 6,0 to 6,0 to 8 , and 0 to 10 weeks of age in $\mathrm{PS} \times \mathrm{KM}$ chickens. For PS $\times \mathrm{KT}$ populations, $c G H$ gene showed significant association with body weight at hatching, and ADG; during 8 to 10 weeks of age. The single nucleotide polymorphism variant confirmed that allele G has positive effects for body weight and ADG. Within carcass traits, $c G H$ revealed a tentative association within the dressing percentage. For the $I G F-I$ gene polymorphism, there were significant associations with body weight at hatching; at 2, 4, and 6 weeks of age and ADG; during 0 to 2, 4 to 6 , and 0 to 6 weeks of age; in all of four Thai broiler populations. There were tentative associations of the $I G F-I$ gene within the percentages of breast muscles and wings. Thus, $c G H$ gene may be used as a candidate gene, to improve growth traits of Thai broilers. (Key Words: $c G H$ Gene, $I G F-I$ Gene, Polymerase Chain Reaction-Restriction Fragment Length Polymorphism, Marker Assisted Selection, Thai Broilers)
\end{abstract}

\section{INTRODUCTION}

Poultry production is an important and diverse component of agriculture all over the world. Today, more attention has been given to indigenous animals in general, and poultry in particular; due to their quality of meat and sustainable production (Kaya and Yildiz, 2008). Meat from Thai native chickens is preferred by more Thai consumers than commercial broilers (Theerachai et al., 2003), due to their superior taste, meat texture, low fat and cholesterol, and high protein content (Promwatee and Duangjinda, 2010). However, the native chickens are inferior in production due to their low growth rates, as compared with

\footnotetext{
* Corresponding Author: Monchai Duangjinda. Tel: +66-43202362, Fax: +66-43-202361, E-mail: monchai@kku.ac.th

${ }^{2}$ Research and Development Network Center for Animal Breeding (Native Chicken), Khon Kaen University, Khon Kaen 40002, Thailand.

Submitted Jan. 9, 2015; Revised Apr. 6, 2015; Accepted May 19, 2015
}

commercial breed production. Promwatee et al. (2013) demonstrated that body weights of Thai synthetic chickens (50\% native genetics) at 14 weeks of age, were between 1,532 to $1,561 \mathrm{~g}$; which is significantly higher than the average body weight $(1,280 \mathrm{~g})$ of the typical 16 week Thai native chicken (Jaturasitha et al., 2008). Additionally, the market price of Thai native chickens is nearly two to three times higher than the commercial broiler (Wattanachant et al., 2004). Nowadays, hybrid chickens (with less than 50\% native genetics) are more desirable for open-housing commercial production, due to the lower cost of production (faster growth) and greater tolerance to heat stress. Cross breeding of parent stock (PS) broiler sires with Thai synthetic breeds, in order to achieve a terminal hybrid of $75 \%$ broiler and $25 \%$ Thai native chicken (referred to as the Thai broiler), is of interest to the modern trait market. The products have a lower price, better taste, and better meat texture; compared to commercial broilers. In this regard, genetic improvements of parental lines for Thai broilers 
must be studied to meet the demands of consumers.

Growth performance and carcass traits are very significant economic traits in broiler production, and are controlled by sets of complex genes. Growth is a complicated procedure, regulated by a wide variety of neuroendocrine pathways (Zhang et al., 2008). For this reason, it is very difficult to make rapid progress using conventional methods of genetic selection within breeds (Zhang et al., 2008). Recent advances in molecular technology have provided new opportunities to evaluate genetic variability at the DNA level (Kaya and Yildiz, 2008). Therefore, the candidate gene approach has become a powerful technique for genetic improvement in the chicken breeding program. Applying a candidate gene may result in higher efficiency in detecting the desired traits necessary to improve production performance. The chicken growth hormone $(c G H)$ and insulin-like growth factor-I (IGF-I) genes are among the most promising candidate genes for growth performance and carcass quality traits in chickens.

The $c G H$ is a $22-\mathrm{kDa}$ protein, containing 191 amino acid residues (Hrabia et al., 2008). In poultry, $c G H$ consists of 4,101 base pairs, having five exons and four introns (Kansaku et al., 2008). Known as a polypeptide, hormone produced, and secreted by pituitary gland; $c G H$ affects a variety of physiological functions in growth performance (Byatt et al., 1993; Apa et al., 1994). In the works of various authors, it was found that $c G H$ gene is one of the most important genes affecting chicken performance traits, and plays a critical role in both growth and metabolism rates (Feng et al., 1997; Vasilatos-Younken et al., 2000).

$I G F-I$ is known as one of the more predominant hormones necessary to support normal growth in chickens (Scanes, 2009; Boschiero et al., 2013). Furthermore, IGF-I is also involved in growth hormone secretion and regulation (Piper and Porter, 1997; Spencer et al., 1997; Rousseau and Dufour, 2007). In previous studies, the chicken $I G F-I$ has been revealed to involve as many as 70 amino acids (Ballard et al., 1990). IGF-I is a complex system of peptide hormones that bind to the insulin-like growth factor I receptor (IGFIR), in order to activate their intrinsic tyrosine kinase domain activities (Denley et al., 2005). Additionally, the effect of $I G F-I$ was observed on the protein synthesis of chicken embryo myoblast, cultured in a serum free medium (Kita and Okumura, 2000). Zhou et al. (2005) and Amills et al. (2003) reported that polymorphism of the $I G F-I$ gene in the promoter and 5'- untranslated region (5'- UTR) was directly associated with chicken growth rate. There were dramatically higher $I G F-I$ concentrations in the high growth rate line chickens, than those in the low growth rate line chickens (Beccavin et al., 2001).

To develop a suitable terminal breeding program it is necessary to study the relationship of $c G H$ and $I G F-I$ genes for use as candidate genes in Thai broilers. The purpose of the present study was to examine the association of $c G H$ and $I G F-I$ genes within the growth performance, and carcass traits in Thai broilers.

\section{MATERIALS AND METHODS}

\section{Chicken populations}

Four Thai broiler hybrids were established by crossing sires from a broiler breeder line (PS) with dams from four Thai synthetic chicken lines; namely, the Kaen Thong (KT), Khai Mook Esarn (KM), Soi Nin (SN), and Soi Pet (SP; Promwatee et al., 2013). A total of 408 individuals from the four Thai broiler lines were studied: $\operatorname{PS} \times \mathrm{KT}(\mathrm{n}=101)$, $\operatorname{PS} \times \mathrm{KM}(\mathrm{n}=104), \mathrm{PS} \times \mathrm{SN}(\mathrm{n}=104)$, and $\mathrm{PS} \times \mathrm{SP}(\mathrm{n}=99)$. Phenotypic characteristics of all chicken lines are shown in Figure 1. All of four different colors of Thai synthetic dam lines are shown while only the white color of Thai broiler lines are shown due to the dominance of white color from PS broiler sire. The sample of Thai broiler chickens were supplied by the Research and Development Network Center for Animal Breeding, Khon Kaen University, Khon Kaen, Thailand. All chickens were fed ad libitum within the commercial broiler diet.

\section{Measurement of growth and carcass traits}

Body weight (BW) of 408 chickens was recorded individually at hatching; and at 2, 4, 6, 8, and 10 weeks of age (BW 0, BW 2, BW 4, BW 6, BW 8, and BW10). The average daily gain (ADG) was calculated at two week intervals: 0 to 2 weeks of age (ADG 0-2), 2 to 4 weeks of age (ADG 2-4), 4 to6 weeks of age (ADG 4-6), 6 to 8 weeks of age (ADG 6-8), 8 to 10 weeks of age (ADG 8-10); as well as 0 to 6 weeks of age (ADG 0-6), 0 to 8 weeks of age (ADG 0-8), and 0 to 10 weeks of age (ADG 0-10). Description of data is described in Table 1 and 2. The formula of ADG was calculated using the equation below:

$$
\begin{aligned}
& \operatorname{ADG}(\mathrm{g} / \text { chick/d }) \\
& =\frac{\text { Final body weight }(\mathrm{g})-\text { Initial body weight }(\mathrm{g})}{\text { Total day of growth period }(\mathrm{d})}
\end{aligned}
$$

A total of 32 chickens were slaughtered at 10 weeks of age ( 8 chickens per line with 4 chickens per sex). All chickens were chosen as a representative sample based on average body weight and sex for each line. Carcass traits included live weight, dressing percentage, and the percentages of the measured breasts, drumsticks, wings, and thighs.

\section{Genotyping with polymerase chain reaction-restriction fragment length polymorphism}

Genomic DNA was extracted from the blood of 408 


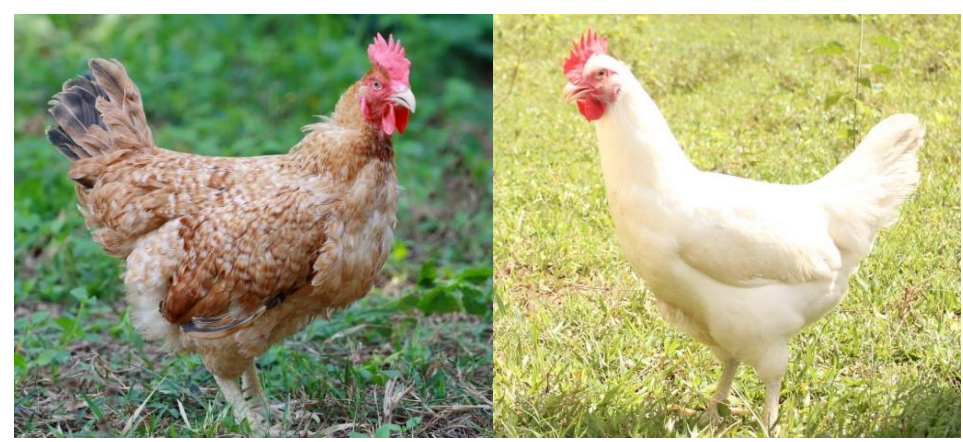

(A)

(B)

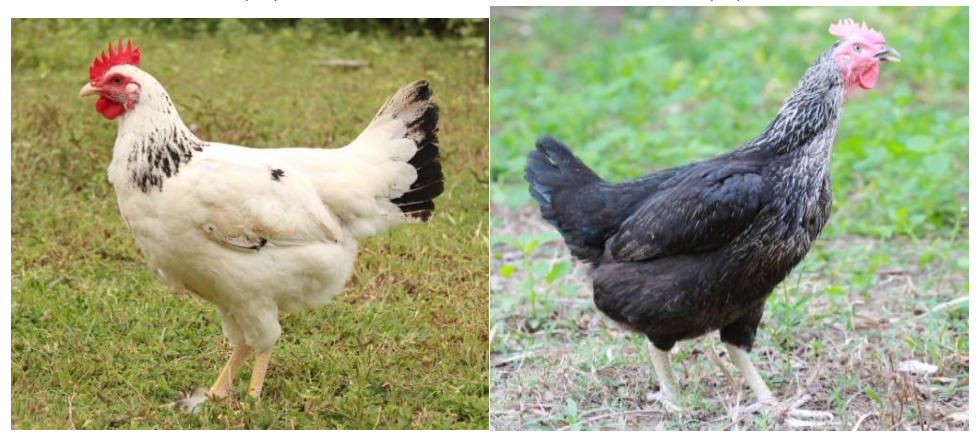

(C)

(D)

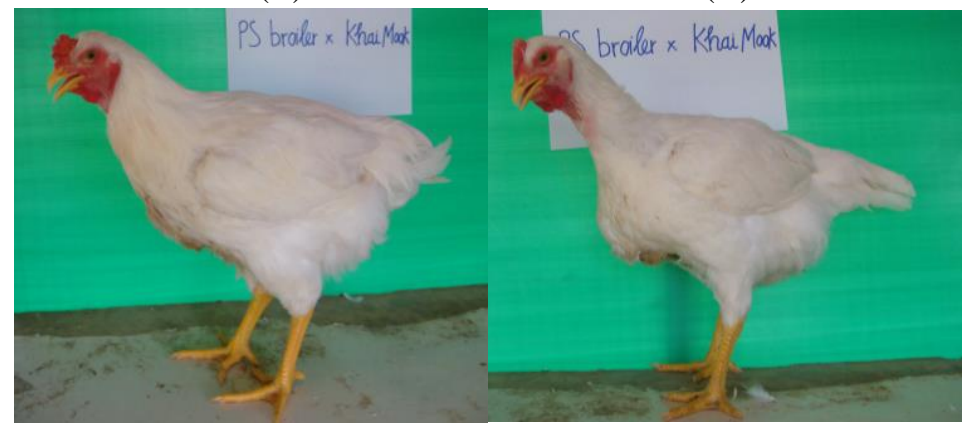

(E)

(F)

Figure 1. Phenotype characteristics of chickens in the mating program to produce Thai broiler. (A) Kaen Thong. (B) Khai Mook Esarn. (C) Soi Nin. (D) Soi Pet dam line. (E) Thai broiler male. (F) Thai broiler female.

chickens. One $\mathrm{mL}$ of each individual blood sample was stored in a micro tube containing $100 \mu \mathrm{L}$ of $0.5 \mathrm{M}$ ethylenediaminetetraacetic acid, as an anti-coagulant. Genomic DNA was isolated by using Guanidine Hydrochloride/Silica gel protocol (Goodwin et al., 2007).

The polymerase chain reaction (PCR) was performed in a $10 \mu \mathrm{L}$ mixture containing $1 \mu \mathrm{L}$ genomic DNA (50 ng), 1 $\mu \mathrm{L} 10 \times$ PCR buffer, $1 \mu \mathrm{L} 2.5 \mu \mathrm{M}$ of primers for each candidate gene, $1 \mu \mathrm{L} 1 \mathrm{mM}$ of dNTP (Thermo scientific, Waltham, MA, USA), $0.8 \mu \mathrm{L} 25 \mathrm{mM} \mathrm{MgCl}_{2}$, and $0.1 \mu \mathrm{L} 5 \mathrm{U}$ Taq DNA polymerase (RBC Bioscience, New Taipei, Taiwan). The primer characteristics of IGF-I (Zhou et al., 2005) and $c G H$ (Nie et al., 2005) are shown in Table 3. PCR amplification was conducted under the following conditions: $95^{\circ} \mathrm{C}$ for five minutes, followed by 30 to 35 cycles at $95^{\circ} \mathrm{C}$ for $45 \mathrm{~s}, 58^{\circ} \mathrm{C}$ to $68^{\circ} \mathrm{C}$ for 30 to $45 \mathrm{~s}$, and $72^{\circ} \mathrm{C}$ for 30 to $45 \mathrm{~s}$; followed by a final extension at $72^{\circ} \mathrm{C}$ for five minutes.
Polymorphisms were detected by using the polymerase chain reaction-restriction fragment length polymorphism technique. The PCR products were digested in a total volume of $20 \mu \mathrm{L}$ of solution; containing $3 \mu \mathrm{L}$ of PCR product, 1 to $2 \mathrm{U}$ of restriction enzymes, buffer, and $\mathrm{H}_{2} \mathrm{O}$. The sample was then incubated at $37^{\circ} \mathrm{C}$ overnight. Restriction patterns were visualized by $2 \%$ agarose gel electrophoresis, and stained in GelStar (GelStarInc, New York, NY, USA). Agarose gels were visualized and photographed under Gel Documentation System standards (SYNGENE, Madison, WI, USA).

\section{Statistical analysis}

Genotypic and allelic frequencies were calculated at each locus, as described by previous authors (Falconer and Mackay, 2001). Genotypes having a frequency lower than $2 \%$ were discarded from the analysis. The association of candidate genes and traits were analyzed with pooled data 
Table 1. Descriptive statistics of data used in gene association study in $\mathrm{PS} \times \mathrm{KT}$ and $\mathrm{PS} \times \mathrm{KM}$ populations

\begin{tabular}{|c|c|c|c|c|c|c|c|c|}
\hline \multirow{2}{*}{ Breed/trait } & \multicolumn{4}{|c|}{ Male } & \multicolumn{4}{|c|}{ Female } \\
\hline & Mean & SD & Min & Max & Mean & SD & Min & Max \\
\hline$\overline{\mathrm{PS} \times \mathrm{KT}}$ & \multicolumn{4}{|c|}{$\mathrm{n}=53$} & \multicolumn{4}{|c|}{$\mathrm{n}=48$} \\
\hline \multicolumn{9}{|l|}{$\mathrm{BW}^{\mathrm{a}}(\mathrm{g})$} \\
\hline 0 & 36.02 & 4.17 & 25 & 45 & 36.19 & 4.35 & 28 & 46 \\
\hline 2 & 206.60 & 50.04 & 120 & 310 & 220.42 & 45.85 & 130 & 310 \\
\hline 4 & 721.51 & 105.75 & 460 & 950 & 683.54 & 97.90 & 420 & 870 \\
\hline 6 & $1,287.55$ & 238.29 & 820 & 1670 & $1,185.00$ & 152.59 & 820 & 1,460 \\
\hline 8 & $1,830.19$ & 309.58 & 1,220 & 2,410 & $1,615.63$ & 224.57 & 1,180 & 1,300 \\
\hline 10 & $2,488.20$ & 356.26 & 1,820 & 3,270 & $2,078.72$ & 260.27 & 1,300 & 2,560 \\
\hline \multicolumn{9}{|c|}{$\mathrm{ADG}^{\mathrm{b}}(\mathrm{g} / \mathrm{d})$} \\
\hline $0-2$ & 12.18 & 3.61 & 5.64 & 19.64 & 13.16 & 3.32 & 6.86 & 19.57 \\
\hline $2-4$ & 36.78 & 4.77 & 22.86 & 45.71 & 33.08 & 4.38 & 20.71 & 42.86 \\
\hline $4-6$ & 40.43 & 12.13 & 12.14 & 58.57 & 35.82 & 6.77 & 12.14 & 51.43 \\
\hline $6-8$ & 38.76 & 14.92 & 6.43 & 59.29 & 30.76 & 10.84 & 7.86 & 44.29 \\
\hline $8-10$ & 46.46 & 11.41 & 15.00 & 65.00 & 33.18 & 7.95 & 8.57 & 48.57 \\
\hline $0-6$ & 29.80 & 5.69 & 18.69 & 39.02 & 27.35 & 3.62 & 18.71 & 33.90 \\
\hline $0-8$ & 32.04 & 5.52 & 21.16 & 42.41 & 28.20 & 4.00 & 20.38 & 35.13 \\
\hline 0-10 & 35.03 & 5.08 & 25.50 & 46.16 & 29.18 & 3.71 & 18.01 & 36.10 \\
\hline $\mathrm{PS} \times \mathrm{KM}$ & \multicolumn{4}{|c|}{$\mathrm{n}=50$} & \multicolumn{4}{|c|}{$\mathrm{n}=54$} \\
\hline \multicolumn{9}{|l|}{ BW (g) } \\
\hline 0 & 36.68 & 2.93 & 29 & 43 & 37.02 & 3.85 & 30 & 46 \\
\hline 2 & 251.20 & 38.58 & 150 & 330 & 249.44 & 39.64 & 90 & 330 \\
\hline 4 & 799.00 & 93.62 & 490 & 960 & 718.52 & 78.61 & 320 & 890 \\
\hline 6 & $1,576.40$ & 179.00 & 1,000 & 2,000 & $1,343.89$ & 108.41 & 900 & 1,600 \\
\hline 8 & $2,147.60$ & 260.76 & 1,310 & 2,660 & $1,778.52$ & 146.22 & 1,450 & 2,040 \\
\hline 10 & $2,677.69$ & 288.48 & 1,730 & 3,220 & $2,217.92$ & 203.61 & 1,780 & 3,000 \\
\hline \multicolumn{9}{|c|}{$\operatorname{ADG}(g / d)$} \\
\hline $0-2$ & 15.32 & 2.77 & 8.07 & 20.86 & 15.17 & 2.85 & 3.79 & 20.29 \\
\hline $2-4$ & 39.13 & 5.43 & 13.57 & 47.86 & 33.51 & 3.50 & 16.43 & 40.00 \\
\hline $4-6$ & 55.53 & 7.16 & 36.43 & 75.71 & 44.67 & 4.40 & 34.29 & 58.57 \\
\hline $6-8$ & 40.80 & 11.99 & 5.00 & 63.57 & 31.04 & 9.02 & 2.14 & 46.43 \\
\hline $8-10$ & 39.91 & 10.46 & 15.71 & 60.71 & 31.48 & 10.69 & 5.71 & 87.86 \\
\hline $0-6$ & 36.66 & 4.27 & 22.88 & 46.81 & 31.12 & 2.58 & 20.55 & 37.00 \\
\hline $0-8$ & 37.70 & 4.65 & 22.70 & 46.89 & 31.10 & 2.60 & 25.27 & 35.77 \\
\hline $0-10$ & 37.73 & 4.11 & 24.16 & 45.51 & 31.16 & 2.90 & 24.86 & 42.37 \\
\hline
\end{tabular}

PS, broiler breeder sire; KT, Kaen Thong; KM, Khai Mook Esarn dam line; SD, standard deviation; BW, body weight (at hatching, 2, 4, 6, 8, and 10 weeks of age); ADG, average daily gain (during 0 to 2,2 to 4,4 to 6,6 to 8,8 to 10,0 to 6,0 to 8 , and 0 to 10 weeks of age).

of four hybrids and adjusted line effect as fixed effect using following model:

the model below:

$$
y_{i j k l}=\mu+G_{i}+S_{j}+H_{k}+C_{l}+C_{l} \times G_{i}+e_{i j k l}
$$

Where $\mathrm{y}_{\mathrm{ijk}}$ is trait observation (BW and $\mathrm{ADG}$ ), $\mu$ is overall population mean, $\mathrm{G}_{\mathrm{i}}$ is the fixed effect of the genotype, $S_{j}$ is the fixed effect of the sex, $H_{k}$ is the fixed effect of the hatching, $C_{l}$ is different hybrid cross effect, $\mathrm{C}_{\mathrm{l}} \times \mathrm{G}_{\mathrm{i}}$ is interaction effect between studied breed and gene, and $\mathrm{e}_{\mathrm{ijk}}$ is the residual random error.

The association of candidate genes and traits were also analyzed separately for each hybrid cross using the

$$
y_{i j k}=\mu+G_{i}+S_{j}+H_{k}+e_{i j k}
$$

Where $\mathrm{y}_{\mathrm{ijk}}, \mu, \mathrm{G}_{\mathrm{i}}, \mathrm{S}_{\mathrm{j}}, \mathrm{H}_{\mathrm{k}}$, and $\mathrm{e}_{\mathrm{ijk}}$ were described above.

For carcass traits, according to the small number of samples, the association between candidate genes and traits were analyzed with pooled data from all hybrid cross, using the model as follow:

$$
y_{i j k l}=\mu+G_{i}+S_{j}+H_{k}+C_{l}+e_{i j k l}
$$

Where $\mathrm{y}_{\mathrm{ijkl}}$ is a trait observation (carcass percentage), $\mu$, 
Table 2. Descriptive statistics of data used in gene association study in $\mathrm{PS} \times \mathrm{SN}$ and $\mathrm{PS} \times \mathrm{SP}$ populations

\begin{tabular}{|c|c|c|c|c|c|c|c|c|}
\hline \multirow{2}{*}{ Breed/trait } & \multicolumn{4}{|c|}{ Male } & \multicolumn{4}{|c|}{ Female } \\
\hline & Mean & SD & Min & Max & Mean & SD & Min & Max \\
\hline$\overline{\mathrm{PS} \times \mathrm{SN}}$ & \multicolumn{4}{|c|}{$\mathrm{n}=50$} & \multicolumn{4}{|c|}{$\mathrm{n}=54$} \\
\hline \multicolumn{9}{|l|}{$\mathrm{BW}^{\mathrm{a}}(\mathrm{g})$} \\
\hline 0 & 33.90 & 2.87 & 27 & 40 & 34.15 & 3.39 & 27 & 41 \\
\hline 2 & 230.61 & 43.18 & 140 & 310 & 236.67 & 38.85 & 120 & 310 \\
\hline 4 & 721.40 & 79.02 & 540 & 870 & 673.15 & 64.16 & 530 & 780 \\
\hline 6 & $1,406.20$ & 151.92 & 1,100 & 1,720 & $1,246.48$ & 106.19 & 1,020 & 1,450 \\
\hline 8 & $2,024.60$ & 190.08 & 1,510 & 2,410 & $1,748.52$ & 159.02 & 1,400 & 2,110 \\
\hline 10 & $2,544.90$ & 217.18 & 2,000 & 3,120 & $2,131.35$ & 239.84 & 1,440 & 2,700 \\
\hline \multicolumn{9}{|c|}{$\mathrm{ADG}^{\mathrm{b}}(\mathrm{g} / \mathrm{d})$} \\
\hline $0-2$ & 14.05 & 3.13 & 7.79 & 19.86 & 14.47 & 2.82 & 5.71 & 19.86 \\
\hline $2-4$ & 35.23 & 3.09 & 27.14 & 42.14 & 31.18 & 2.77 & 25.71 & 36.43 \\
\hline $4-6$ & 48.91 & 7.07 & 32.86 & 60.71 & 40.95 & 4.49 & 32.14 & 51.43 \\
\hline $6-8$ & 44.17 & 7.57 & 25.00 & 56.43 & 35.86 & 5.91 & 22.14 & 49.29 \\
\hline $8-10$ & 37.04 & 10.45 & 16.43 & 60.71 & 27.43 & 9.52 & 2.86 & 56.43 \\
\hline $0-6$ & 32.67 & 3.62 & 25.38 & 40.14 & 28.87 & 2.53 & 23.40 & 33.76 \\
\hline $0-8$ & 35.55 & 3.40 & 26.36 & 42.45 & 30.61 & 2.84 & 24.46 & 37.09 \\
\hline 0-10 & 35.87 & 3.11 & 28.10 & 44.10 & 29.96 & 3.42 & 20.14 & 38.01 \\
\hline $\mathrm{PS} \times \mathrm{SP}$ & \multicolumn{4}{|c|}{$\mathrm{n}=41$} & \multicolumn{4}{|c|}{$\mathrm{n}=58$} \\
\hline \multicolumn{9}{|l|}{ BW (g) } \\
\hline 0 & 35.32 & 3.30 & 29 & 42 & 34.41 & 2.97 & 28 & 41 \\
\hline 2 & 221.71 & 41.35 & 150 & 310 & 218.62 & 38.95 & 150 & 310 \\
\hline 4 & 722.68 & 105.38 & 510 & 930 & 656.72 & 68.48 & 450 & 830 \\
\hline 6 & $1,375.85$ & 213.18 & 750 & 1,730 & $1,187.59$ & 129.09 & 840 & 1,480 \\
\hline 8 & $1,875.12$ & 300.51 & 790 & 2,390 & $1,631.21$ & 169.55 & 1,340 & 2,180 \\
\hline 10 & $2,491.84$ & 314.71 & 1,500 & 3,050 & $2,076.43$ & 199.33 & 1,800 & 2,690 \\
\hline \multicolumn{9}{|c|}{$\operatorname{ADG}(\mathrm{g} / \mathrm{d})$} \\
\hline $0-2$ & 13.31 & 3.00 & 8.07 & 19.64 & 13.16 & 2.84 & 7.93 & 19.50 \\
\hline $2-4$ & 35.78 & 5.37 & 25.00 & 46.43 & 31.29 & 3.44 & 20.71 & 40.00 \\
\hline $4-6$ & 46.66 & 10.90 & 17.14 & 64.29 & 37.92 & 7.05 & 15.00 & 50.00 \\
\hline $6-8$ & 35.66 & 13.45 & 2.14 & 55.71 & 31.69 & 9.50 & 11.43 & 59.29 \\
\hline $8-10$ & 41.69 & 13.65 & 2.14 & 65.00 & 31.85 & 7.05 & 14.29 & 50.00 \\
\hline $0-6$ & 31.92 & 5.08 & 17.00 & 40.26 & 27.46 & 3.08 & 19.21 & 34.48 \\
\hline $0-8$ & 32.85 & 5.38 & 13.46 & 42.14 & 28.51 & 3.03 & 23.27 & 38.36 \\
\hline $0-10$ & 35.09 & 4.50 & 20.84 & 43.01 & 29.17 & 2.84 & 25.29 & 37.89 \\
\hline
\end{tabular}

PS, broiler breeder sire; SN, Soi Nin; SP, Soi Pet dam line; SD, standard deviation; BW, body weight (at hatching, 2, 4, 6, 8, and 10 weeks of age); ADG, average daily gain (during 0 to 2,2 to 4,4 to 6,6 to 8,8 to 10,0 to 6,0 to 8 , and 0 to 10 weeks of age).

$G_{i}, S_{j}, H_{k}, C_{l}$ were described in previous model.

\section{RESULTS AND DISCUSSION}

Genotype and allele frequencies of $c G H$ and $I G F-I$ genes

Genotype and allele frequencies of $c G H$ and $I G F-I$ genes were calculated after genotyping the populations of four Thai broiler lines, as listed in Table 4. For the $c G H$ gene, allele $\mathrm{G}$ is predominantly higher than allele $\mathrm{A}$, in all four chicken populations. However, the AA genotype was counted with a frequency of 0.05 in the observations of $\mathrm{PS} \times \mathrm{KM}$, and $\mathrm{PS} \times \mathrm{SN}$ populations. The AA genotype showed the lowest frequency (0.01) in the $\mathrm{PS} \times \mathrm{SP}$ population compared with the three other lines. For the

Table 3. Details of single nucleotide polymorphism markers and primers

\begin{tabular}{|c|c|c|c|c|c|}
\hline Gene & Primer (forward/reverse) & AT $\left({ }^{\circ} \mathrm{C}\right)$ & SNPs/site & PCRproduct (bp) & Enzyme \\
\hline$c G H$ & $\begin{array}{l}\text { 5'-TCCCAGGCTGCGTTTTGTTACTC-3' } \\
\text { 5'-ACGGGGGTGAGCCAGGACTG-3' }\end{array}$ & 65 & $\begin{array}{c}\mathrm{G}>\mathrm{A} / \\
1705 \text { intron } 3\end{array}$ & 429 & EcoRV \\
\hline$I G F-I$ & $\begin{array}{l}\text { 5'-TCAAGAGAAGCCCTTCAAGC-3' } \\
\text { 5'-CATTGCGCAGGCTCTATCTG-3' }\end{array}$ & 60 & $\begin{array}{l}\mathrm{A}>\mathrm{C} / \\
\text { moter and } 5\end{array}$ & 813 & HinfI \\
\hline
\end{tabular}

AT, annealing temperature; SNP, single nucleotide polymorphism; PCR, polymerase chain reaction; $c G H$, chicken growth hormone gene; $I G F-I$, insulinlike growth factor-I gene. 
Table 4. Genotype and allele frequencies of $c G H$ and $I G F-I$ genes in Thai broilers

\begin{tabular}{ccccccc}
\hline Gene/breeds & \multicolumn{1}{c}{ No. } & \multicolumn{3}{c}{ Genotype frequencies } & \multicolumn{3}{c}{ Allele frequencies } \\
\hline$c G H$ & & AA & AG & GG & A & G \\
$\mathrm{PS} \times \mathrm{KM}$ & 104 & 0.05 & 0.30 & 0.65 & 0.20 & 0.80 \\
$\mathrm{PS} \times \mathrm{KT}$ & 101 & 0.16 & 0.46 & 0.39 & 0.30 & 0.61 \\
$\mathrm{PS} \times \mathrm{SN}$ & 104 & 0.05 & 0.48 & 0.47 & 0.29 & 0.71 \\
$\mathrm{PS} \times \mathrm{SP}$ & 99 & 0.01 & 0.52 & 0.47 & 0.27 & 0.73 \\
$I G F-I$ & & $\mathrm{AA}$ & $\mathrm{AC}$ & $\mathrm{CC}$ & $\mathrm{A}$ & $\mathrm{C}$ \\
$\mathrm{PS} \times \mathrm{KM}$ & 104 & 0.42 & 0.44 & 0.13 & 0.64 & 0.36 \\
$\mathrm{PS} \times \mathrm{KT}$ & 101 & 0.31 & 0.54 & 0.15 & 0.58 & 0.42 \\
$\mathrm{PS} \times \mathrm{SN}$ & 104 & 0.43 & 0.42 & 0.14 & 0.64 & 0.36 \\
$\mathrm{PS} \times \mathrm{SP}$ & 99 & 0.15 & 0.71 & 0.14 & 0.51 & 0.49 \\
\hline
\end{tabular}

$c G H$, chicken growth hormone gene; $I G F-I$, insulin-like growth factor-I gene; PS, broiler breeder sire; KM, KhaiMookEsarn; KT, Kaen Thong; SN, Soi Nin; SP, Soi Pet dam line.

IGF-I gene, the CC genotype was observed in all populations with lower frequencies $(0.13$ to 0.15$)$ compared to that of the other genotypes.

\section{Association of $c G H$ and $I G F-I$ gene polymorphisms with growth traits}

The analysis of association between the $c G H$ and $I G F-I$ gene polymorphisms and growth performance traits across all of four Thai chicken lines is shown in Table 5. A significant interaction between breed and gene was not found in almost all observed traits $(\mathrm{p}<0.05)$; except body weight at 4 and ADG at 2 to 4 weeks of age $(p<0.05)$. The association of $c G H$ gene was found in body weight trait at 4 and 6 weeks of age; and ADG at 2 to 4 and 0 to 6 weeks of age. Chicken with AG and GG genotypes showed higher BW and ADG $(p<0.05)$ compared to that of the AA genotype. The analysis of the potential association between the $c G H$ gene polymorphism and growth performance traits is summarized in Table 6. In the PS $\times \mathrm{KM}$ hybrid, chickens with AG and GG genotypes demonstrated higher BW and ADG $(p<0.01)$ compared to that of the AA genotype. Significant associations of $c G H$ were found with only BW at hatching, and ADG 8-10 in $\mathrm{PS} \times \mathrm{KT}$ population $(\mathrm{p}<0.05)$. The $c G H$ genotype effects ( $p>0.05$ ) were not found in other hybrids $(\mathrm{PS} \times \mathrm{SP}$ and $\mathrm{PS} \times \mathrm{SN})$.

Nie et al. (2005) reported that the single nucleotide polymorphism (SNP) within the same region (G1705A) maintained a significant association with almost all growth traits, in an $F_{2}$ reciprocal cross between the WRR and X Chinese chicken breeds. The allele A in the study by Nie et al. (2005) showed a positive effect on growth traits. However, our study concluded that allele G exhibited a generally positive effect on chicken growth and was completely dominant in all breeds (AG and GG having similar effects). These results confirm those found in the previous study of Thai native chickens (Chee), which revealed that all growth traits, including body weight and ADG, from 0 to 16 weeks of age; were significantly higher in the GG genotypes (Promwatee and Duangjinda, 2010).

The results of this study indicate that the $c G H$ gene is associated with body weight and ADG in almost all recorded periods, within the $\mathrm{PS} \times \mathrm{KM}$ population. In this

Table 5. Least square means of $c G H$ and $I G F-I$ genes on growth traits in Thai broilers across all chicken populations

\begin{tabular}{|c|c|c|c|c|c|c|c|c|}
\hline \multirow[b]{2}{*}{ Growth traits } & \multicolumn{4}{|c|}{$c G H$} & \multicolumn{4}{|c|}{$I G F-I$} \\
\hline & $\begin{array}{c}\text { AA } \\
(n=27)\end{array}$ & $\begin{array}{c}\mathrm{AG} \\
(\mathrm{n}=178)\end{array}$ & $\begin{array}{c}\text { GG } \\
(\mathrm{n}=203)\end{array}$ & SEM & $\begin{array}{c}\text { AA } \\
(n=135)\end{array}$ & $\begin{array}{c}\mathrm{AC} \\
(\mathrm{n}=215)\end{array}$ & $\begin{array}{c}\mathrm{CC} \\
(\mathrm{n}=58)\end{array}$ & SEM \\
\hline \multicolumn{9}{|l|}{ BW (g) } \\
\hline 0 & 37.1 & 36.4 & 35.8 & 0.5 & 36.7 & 36.0 & 36.1 & 0.3 \\
\hline 2 & 204.8 & 213.2 & 213.8 & 5.4 & $219.8^{\mathrm{a}}$ & $210.4^{b}$ & $208.6^{\mathrm{b}}$ & 3.6 \\
\hline 4 & $639.3^{\mathrm{b}}$ & $696.0^{\mathrm{a}}$ & $700.1^{\mathrm{a}}$ & 12.5 & 704.4 & 691.0 & 696.1 & 8.5 \\
\hline 6 & $1,161.0^{\mathrm{b}}$ & $1,268.3^{\mathrm{a}}$ & $1,268.9^{\mathrm{a}}$ & 23.2 & $1,276.2$ & $1,265.3$ & $1,239.6$ & 15.8 \\
\hline 8 & $1,689.7$ & $1,782.2$ & $1,788.2$ & 35.0 & $1,794.7$ & $1,782.5$ & $1,785.5$ & 23.8 \\
\hline 10 & $2,194.4$ & $2,296.4$ & $2,325.9$ & 42.4 & $2,298.4$ & $2,304.6$ & $2,303.0$ & 29.4 \\
\hline \multicolumn{9}{|l|}{$\operatorname{ADG}(\mathrm{g} / \mathrm{d})$} \\
\hline $0-2$ & 12.0 & 12.6 & 12.7 & 0.4 & $13.1^{\mathrm{a}}$ & $12.5^{b}$ & $12.3^{b}$ & 0.3 \\
\hline $2-4$ & $31.1^{\mathrm{B}}$ & $34.5^{\mathrm{A}}$ & $34.7^{\mathrm{A}}$ & 0.6 & 34.6 & 34.4 & 34.8 & 0.4 \\
\hline $4-6$ & 37.3 & 40.9 & 40.6 & 1.1 & $40.8^{\mathrm{ab}}$ & $41.0^{\mathrm{a}}$ & $38.8^{\mathrm{b}}$ & 0.7 \\
\hline $6-8$ & 37.8 & 36.7 & 37.1 & 1.7 & 37.0 & 36.9 & 39.0 & 1.2 \\
\hline $8-10$ & 35.5 & 36.6 & 37.7 & 1.6 & 36.0 & 36.7 & 37.4 & 1.1 \\
\hline $0-6$ & $26.8^{\mathrm{b}}$ & $29.3^{\mathrm{a}}$ & $29.4^{\mathrm{a}}$ & 0.5 & 29.5 & 28.3 & 28.7 & 0.4 \\
\hline $0-8$ & 29.5 & 31.2 & 31.3 & 0.6 & 31.4 & 31.2 & 31.2 & 0.4 \\
\hline $0-10$ & 30.8 & 32.3 & 32.7 & 0.6 & 32.3 & 32.4 & 32.4 & 0.4 \\
\hline
\end{tabular}

$c G H$, chicken growth hormone gene; IGF-I, insulin-like growth factor-I gene; SEM, standard error of the mean; BW, body weight (at hatching 2, 4, 6, 8, and 10 weeks of age); ADG, average daily gain (during 0 to 2,2 to 4,4 to 6,6 to 8,8 to 10,0 to 6,0 to 8 , and 0 to 10 weeks of age).

${ }_{\mathrm{A}, \mathrm{B}}$ Means within a row without common superscript capital letters differ significantly $(\mathrm{p}<0.01)$.

${ }^{a, b}$ Means within a row without common superscript lowercases differ significantly $(\mathrm{p}<0.05)$. 
Table 6. Least square means of $c G H$ gene on growth performance in Thai broiler populations

\begin{tabular}{|c|c|c|c|c|c|c|c|c|c|c|c|c|c|c|}
\hline \multirow{3}{*}{ Breed/genotype } & \multicolumn{14}{|c|}{ Growth performance traits } \\
\hline & \multicolumn{6}{|c|}{$\mathrm{BW}(\mathrm{g})$} & \multicolumn{8}{|c|}{$\operatorname{ADG}(g / d)$} \\
\hline & 0 & 2 & 4 & 6 & 8 & 10 & $0-2$ & $2-4$ & $4-6$ & $6-8$ & $8-10$ & $0-6$ & $0-8$ & $0-10$ \\
\hline \multicolumn{15}{|l|}{$\overline{\mathrm{PS} \times \mathrm{KM}}$} \\
\hline $\mathrm{AA}(\mathrm{n}=5)$ & 38.4 & 228.0 & $626.8^{\mathrm{B}}$ & $1,228.9^{\mathrm{B}}$ & $1,689.8^{\mathrm{B}}$ & $2,162.0^{\mathrm{b}}$ & 13.5 & $28.5^{\mathrm{B}}$ & $43.0^{\mathrm{B}}$ & 32.9 & 32.7 & $28.3^{\mathrm{B}}$ & $29.5^{\mathrm{b}}$ & $30.3^{b}$ \\
\hline $\mathrm{AG}(\mathrm{n}=31)$ & 37.9 & 237.5 & $732.7^{\mathrm{A}}$ & $1,438.9^{\mathrm{A}}$ & $1,940.2^{\mathrm{A}}$ & $2,427.4^{\mathrm{a}}$ & 14.3 & $35.4^{\mathrm{A}}$ & $50.4^{\mathrm{A}}$ & 35.8 & 35.6 & $33.4^{\mathrm{A}}$ & $34.0^{\mathrm{a}}$ & $34.1^{\mathrm{a}}$ \\
\hline $\mathrm{GG}(\mathrm{n}=68)$ & 38.2 & 237.6 & $752.2^{\mathrm{A}}$ & $1,453.1^{\mathrm{A}}$ & $1,987.3^{\mathrm{A}}$ & $2,472.8^{\mathrm{a}}$ & 14.2 & $36.8^{\mathrm{A}}$ & $50.1^{\mathrm{A}}$ & 38.2 & 35.7 & $33.7^{\mathrm{A}}$ & $34.8^{\mathrm{a}}$ & $34.8^{\mathrm{a}}$ \\
\hline SEM & 0.8 & 9.9 & 21.5 & 36.8 & 54.9 & 71.0 & 0.7 & 1.1 & 1.5 & 2.8 & 3.2 & 0.9 & 1.0 & 1.0 \\
\hline \multicolumn{15}{|l|}{$\mathrm{PS} \times \mathrm{KT}$} \\
\hline $\mathrm{AA}(\mathrm{n}=16)$ & $37.9^{\mathrm{a}}$ & 209.4 & 674.9 & $1,170.0$ & $1,723.0$ & $2,258.4$ & 12.2 & 33.3 & 35.4 & 39.3 & $38.2^{\mathrm{b}}$ & 27.0 & 30.1 & 31.7 \\
\hline $\mathrm{AG}(\mathrm{n}=46)$ & $37.3^{\mathrm{a}}$ & 203.4 & 689.4 & $1,182.5$ & $1,670.6$ & $2,201.8$ & 11.9 & 34.7 & 35.2 & 34.8 & $37.8^{\mathrm{b}}$ & 27.3 & 29.2 & 30.9 \\
\hline GG $(\mathrm{n}=39)$ & $34.9^{\mathrm{b}}$ & 206.9 & 705.0 & $1,202.8$ & $1,666.5$ & $2,295.3$ & 12.3 & 35.6 & 35.6 & 33.8 & $44.3^{\mathrm{a}}$ & 27.8 & 29.1 & 32.3 \\
\hline SEM & 0.7 & 7.8 & 18.4 & 34.0 & 52.9 & 61.7 & 0.5 & 0.9 & 1.7 & 2.5 & 2.0 & 0.8 & 0.9 & 0.9 \\
\hline \multicolumn{15}{|l|}{$\mathrm{PS} \times \mathrm{SN}$} \\
\hline $\mathrm{AA}(\mathrm{n}=5)$ & 35.0 & 232.3 & 703.3 & $1,311.4$ & $1,844.2$ & $2,337.5$ & 14.1 & 33.8 & 43.4 & 38.1 & 35.2 & 30.4 & 32.3 & 32.9 \\
\hline $\mathrm{AG}(\mathrm{n}=50)$ & 33.7 & 229.6 & 701.0 & $1,320.5$ & $1,899.1$ & $2,366.5$ & 14.0 & 33.8 & 44.3 & 41.3 & 33.3 & 30.6 & 33.3 & 33.3 \\
\hline GG $(\mathrm{n}=49)$ & 34.1 & 232.5 & 692.9 & $1,314.7$ & $1,869.1$ & $2,326.5$ & 14.2 & 32.9 & 44.4 & 39.6 & 32.8 & 30.5 & 32.8 & 32.8 \\
\hline SEM & 0.7 & 7.3 & 15.5 & 30.9 & 43.2 & 62.1 & 0.5 & 0.7 & 1.5 & 1.8 & 2.5 & 0.7 & 0.8 & 0.9 \\
\hline \multicolumn{15}{|l|}{$\mathrm{PS} \times \mathrm{SP}$} \\
\hline $\mathrm{AG}(\mathrm{n}=51)$ & 35.0 & 216.9 & 701.5 & $1,264.2$ & $1,762.6$ & $2,287.9$ & 13.0 & 34.6 & 40.2 & 35.6 & 37.3 & 29.3 & 30.9 & 32.2 \\
\hline $\mathrm{GG}(\mathrm{n}=47)$ & 34.6 & 212.5 & 682.7 & $1,229.5$ & $1,725.0$ & $2,270.0$ & 12.7 & 33.6 & 39.1 & 35.4 & 36.3 & 28.4 & 30.2 & 31.9 \\
\hline SEM & 0.5 & 4.9 & 13.6 & 25.6 & 39.5 & 47.2 & 0.3 & 0.7 & 1.2 & 1.9 & 1.8 & 0.6 & 0.7 & 0.70 \\
\hline
\end{tabular}

$\mathrm{BW}$, body weight (at hatching 2, 4, 6, 8, and 10 weeks of age); ADG, average daily gain (during 0 to 2,2 to 4,4 to 6,6 to 8,8 to 10,0 to 6,0 to 8 , and 0 to 10 weeks of age); PS, broiler breeder sire; KM, Khai Mook Esarn; SEM, standard error of the mean; KT, Kaen Thong; SN, Soi Nin; SP, Soi Pet dam line.

A, B Means within a column without common superscript capital letters differ significantly $(\mathrm{p}<0.01)$.

${ }^{\mathrm{a}, \mathrm{b}}$ Means within a column without common superscript lowercases differ significantly $(\mathrm{p}<0.05)$.

regard, the G1705A in intron 3 of $c G H$ could have a direct effect on chicken growth performance by mediating $c G H$ expression. Previous studies on other polymorphism in introns of the $c G H$ gene also pointed out the association between chicken growth and carcass traits (Yan et al., 2003; Mehdi and Reza, 2012; Mu'in and Lumatauw, 2013). Hence, the $c G H$ gene could be a potential marker for use in a marker-assisted selection programs. Further study of the associations between $c G H$ and growth traits will be required to obtain more accurate results.

For $I G F-I$ gene when the data was analyzed across all chicken populations (Table 5), the interaction between breed and gene was significant only at ADG during 0 to 2 weeks of age $(p<0.05)$. There were significant associations of $I G F-I$ gene with BW at 2 weeks of age; and with ADG at 0 to 2 and 4 to 6 weeks of age. Chickens with AA genotype showed higher body weight and ADG; except ADG during 4 to 6 weeks, while the AC genotype showed a higher result. The effects of polymorphism of the IGF-I gene on growth traits in Thai broilers is presented in Table 7. It was found that the IGF-I gene polymorphisms showed significant associations with only early periods of chicken growth in each of the four hybrid chickens $(\mathrm{p}<0.05)$. The IGF-I gene was chosen as a candidate gene to examine the associations of gene polymorphism in growth traits, within commercial broilers (Zhou et al., 2005; Kaya and Yıldı, 2008), synthetic breeds (Promwatee et al., 2013), and Thai native chickens (Chee) (Promwatee and Duangjinda, 2010). However, the association with the same region of IGF1SNP1 in two chicken strains of the Black Penedesenca breed, showed only the association with ADG at 107d within a single strain (Amills et al., 2003). The results of this study indicate that the IGF-I gene had an effect on body weight and ADG in the early ages of all four hybrid crosses. However, the genotype effects were not clear. Therefore, this gene was regarded as still unsuitable for use as a marker for parental selection.

The SNP variation in terms of allele substation effect against total genetic effect of $c G H$ and IGF-I gene on growth performance traits across all chicken populations also was calculated and showed in Table 8. It was found allele A of $c G H$ has negative effects for BW at most of ages from week 2 to 10. Chicken with AA had the lowest BW compared to other genotypes. The allele substitution effects are not clear for IGF-I.

\section{Association of $c G H$ and $I G F-I$ gene polymorphisms with carcass traits}

The probability values of the main effects of the $c G H$ and IGF-I gene polymorphisms on chicken carcass traits are 
Table 7. Least square means of $I G F-I$ gene on growth performance in Thai broiler populations

\begin{tabular}{|c|c|c|c|c|c|c|c|c|c|c|c|c|c|c|}
\hline \multirow{3}{*}{$\begin{array}{l}\text { Breeds/ } \\
\text { genotype }\end{array}$} & \multicolumn{14}{|c|}{ Growth performance traits } \\
\hline & \multicolumn{6}{|c|}{$\mathrm{BW}(\mathrm{g})$} & \multicolumn{8}{|c|}{ ADG (g/d) } \\
\hline & 0 & 2 & 4 & 6 & 8 & 10 & $0-2$ & $2-4$ & $4-6$ & $6-8$ & $8-10$ & $0-6$ & $0-8$ & $0-10$ \\
\hline \multicolumn{15}{|l|}{$\overline{\mathrm{PS} \times \mathrm{KM}}$} \\
\hline $\mathrm{AA}(\mathrm{n}=44)$ & 38.5 & $247.2^{\mathrm{a}}$ & 711.6 & $1,376.8$ & $1,870.2$ & $2,383.3$ & $14.9^{\mathrm{a}}$ & 33.2 & 47.5 & 35.2 & 36.9 & 31.9 & 32.7 & 33.5 \\
\hline $\mathrm{AC}(\mathrm{n}=46)$ & 37.6 & $235.8^{\mathrm{ab}}$ & 705.3 & $1,362.2$ & $1,869.8$ & $2,341.1$ & $14.2^{\mathrm{ab}}$ & 33.5 & 46.9 & 36.3 & 33.8 & 31.5 & 32.7 & 32.9 \\
\hline $\mathrm{CC}(\mathrm{n}=14)$ & 38.4 & $220.1^{\mathrm{b}}$ & 694.8 & $1,382.0$ & $1,877.2$ & $2,337.7$ & $13.0^{\mathrm{b}}$ & 33.9 & 49.1 & 35.4 & 33.3 & 32.0 & 32.8 & 32.8 \\
\hline SEM & 0.7 & 8.9 & 19.4 & 33.3 & 49.6 & 64.7 & 0.6 & 1.0 & 1.4 & 2.6 & 2.9 & 0.8 & 0.9 & 0.9 \\
\hline \multicolumn{15}{|l|}{$\mathrm{PS} \times \mathrm{KT}$} \\
\hline $\mathrm{AA}(\mathrm{n}=31)$ & 37.4 & 210.4 & 697.5 & $1,207.9^{\mathrm{ab}}$ & $1,673.2$ & $2,230.8$ & 12.4 & 34.8 & $36.5^{\mathrm{ab}}$ & 33.1 & 39.4 & $27.9^{\mathrm{ab}}$ & 29.2 & 31.3 \\
\hline $\mathrm{AC}(\mathrm{n}=55)$ & 36.6 & 206.2 & 692.7 & $1,227.5^{\mathrm{a}}$ & $1,729.5$ & $2,290.7$ & 12.1 & 34.8 & $38.2^{\mathrm{a}}$ & 36.5 & 39.9 & $28.4^{\mathrm{a}}$ & 30.2 & 32.2 \\
\hline $\mathrm{CC}(\mathrm{n}=15)$ & 36.2 & 203.0 & 679.0 & $1,120.0^{\mathrm{b}}$ & $1,657.4$ & $2,234.0$ & 11.9 & 34.0 & $31.5^{\mathrm{b}}$ & 38.3 & 41.1 & $25.8^{\mathrm{b}}$ & 29.0 & 31.4 \\
\hline SEM & 0.7 & 7.8 & 18.6 & 34.3 & 53.4 & 62.2 & 0.5 & 0.9 & 1.7 & 2.6 & 2.0 & 0.8 & 0.9 & 0.9 \\
\hline \multicolumn{15}{|l|}{$\mathrm{PS} \times \mathrm{SN}$} \\
\hline $\mathrm{AA}(\mathrm{n}=45)$ & $35.5^{\mathrm{a}}$ & $229.0^{\mathrm{ab}}$ & $692.7^{\mathrm{ab}}$ & $1,320.0$ & $1,881.3$ & $2,329.3$ & $13.8^{\mathrm{ab}}$ & 33.1 & 44.8 & 40.1 & 32.2 & 30.6 & 33.0 & 32.8 \\
\hline $\mathrm{AC}(\mathrm{n}=44)$ & $34.0^{\mathrm{b}}$ & $222.9^{\mathrm{b}}$ & $682.0^{\mathrm{b}}$ & 307.0 & $1,839.8$ & $2,322.9$ & $13.5^{\mathrm{b}}$ & 33.0 & 44.6 & 38.1 & 34.4 & 30.3 & 32.2 & 32.7 \\
\hline $\mathrm{CC}(\mathrm{n}=15)$ & $33.4^{\mathrm{b}}$ & $242.6^{\mathrm{a}}$ & $722.5^{\mathrm{a}}$ & $1,319.5$ & $1,891.3$ & $2,378.3$ & $14.9^{\mathrm{a}}$ & 34.3 & 42.6 & 40.8 & 34.7 & 30.6 & 33.2 & 33.5 \\
\hline SEM & 0.7 & 6.6 & 14.0 & 28.0 & 39.0 & 56.5 & 0.5 & 0.7 & 1.4 & 1.6 & 2.3 & 0.7 & 0.7 & 0.8 \\
\hline \multicolumn{15}{|l|}{$\mathrm{PS} \times \mathrm{SP}$} \\
\hline $\mathrm{AA}(\mathrm{n}=15)$ & 34.5 & $255.8^{\mathrm{a}}$ & 698.3 & $1,253.9$ & $1,736.7$ & $2,229.0$ & $13.7^{\mathrm{a}}$ & 39.7 & 34.5 & 33.7 & 33.4 & 29.0 & 30.4 & 31.4 \\
\hline $\mathrm{AC}(\mathrm{n}=70)$ & 35.2 & $213.6^{\mathrm{ab}}$ & 683.5 & $1,257.0$ & $1,733.2$ & $2,279.2$ & $12.7^{\mathrm{ab}}$ & 41.0 & 34.0 & 37.3 & 37.0 & 29.1 & 30.3 & 32.1 \\
\hline $\mathrm{CC}(\mathrm{n}=14)$ & 34.7 & $204.8^{\mathrm{b}}$ & 694.5 & $1,229.6$ & $1,761.6$ & $2,328.6$ & $12.1^{\mathrm{b}}$ & 38.2 & 38.0 & 39.4 & 39.1 & 28.5 & 30.8 & 32.8 \\
\hline SEM & 0.6 & 6.2 & 17.3 & 32.5 & 50.1 & 53.3 & 0.4 & 1.6 & 2.5 & 4.6 & 2.3 & 0.8 & 0.9 & 0.8 \\
\hline
\end{tabular}

$\mathrm{BW}$, body weight (at hatching 2,4,6,8, and 10 weeks of age); ADG, average daily gain (during 0 to 2,2 to 4,4 to 6,6 to 8,8 to 10,0 to 6,0 to 8 , and 0 to 10 weeks of age); PS, broiler breeder sire; KM, Khai Mook Esarn; SEM, standard error of the mean; KT, Kaen Thong; SN, Soi Nin; SP, Soi Pet dam line.

${ }^{a, b}$ Means within a column without common superscript lowercases differ significantly $(\mathrm{p}<0.05)$

Table 8. The single nucleotide polymorphism variation in terms of allele substitution effect against total genetic effect of $c G H$ and $I G F-I$ genes on growth traits across all chicken populations

\begin{tabular}{|c|c|c|c|c|c|c|}
\hline \multirow[b]{2}{*}{ Growth traits } & \multicolumn{3}{|c|}{$c G H$} & \multicolumn{3}{|c|}{$I G F-I$} \\
\hline & $\begin{array}{c}\text { AA } \\
(n=27)\end{array}$ & $\begin{array}{c}\mathrm{AG} \\
(\mathrm{n}=178)\end{array}$ & $\begin{array}{c}\text { GG } \\
(n=203)\end{array}$ & $\begin{array}{c}\text { AA } \\
(n=135)\end{array}$ & $\begin{array}{c}\text { AC } \\
(n=215)\end{array}$ & $\begin{array}{c}\mathrm{CC} \\
(\mathrm{n}=58)\end{array}$ \\
\hline \multicolumn{7}{|l|}{$\overline{\mathrm{BW}}(\mathrm{g})$} \\
\hline 0 & 0.27 & 0.01 & -0.28 & -0.39 & 0.37 & 0.02 \\
\hline 2 & -24.73 & 14.45 & 10.29 & 11.44 & -1.37 & -10.06 \\
\hline 4 & -72.93 & 45.62 & 27.31 & 8.41 & -10.25 & 1.83 \\
\hline 6 & -124.51 & 81.15 & 43.37 & 8.31 & 7.11 & -15.41 \\
\hline 8 & -109.69 & 66.18 & 43.52 & 4.62 & -21.48 & 16.86 \\
\hline 10 & -117.46 & 62.17 & 55.30 & -41.29 & -4.22 & 45.52 \\
\hline \multicolumn{7}{|l|}{$\operatorname{ADG}(\mathrm{g} / \mathrm{d})$} \\
\hline $0-2$ & -1.79 & 1.03 & 0.75 & 0.85 & -0.12 & -0.72 \\
\hline $2-4$ & -3.42 & 2.21 & 1.21 & -0.21 & -0.64 & 0.85 \\
\hline $4-6$ & -3.68 & 2.54 & 1.15 & -0.01 & 1.24 & -1.23 \\
\hline $6-8$ & 1.06 & -1.07 & 0.01 & -0.26 & -2.04 & 2.31 \\
\hline $8-10$ & -0.36 & 0.67 & -0.32 & -3.03 & 0.49 & 2.54 \\
\hline $0-6$ & -2.97 & 1.93 & 1.04 & 0.20 & 0.16 & -0.37 \\
\hline $0-8$ & -1.97 & 1.18 & 0.78 & 0.09 & -0.39 & 0.30 \\
\hline $0-10$ & -1.68 & 0.89 & 0.79 & -0.58 & -0.06 & 0.65 \\
\hline
\end{tabular}

$c G H$, chicken growth hormone gene; $I G F-I$, insulin-like growth factor-I gene.

BW, body weight (at hatching 2, 4, 6, 8, and 10 weeks of age); ADG, average daily gain (during 0 to 2,2 to 4,4 to 6,6 to 8,8 to 10,0 to 6,0 to 8 , and 0 to10 weeks of age). 
Table 9. Least square means of $c G H$ and $I G F-I$ genes on carcass traits in Thai broilers

\begin{tabular}{|c|c|c|c|c|c|}
\hline \multirow{2}{*}{ Gene/genotype } & \multicolumn{5}{|c|}{ Carcass traits $(\%)$} \\
\hline & Dressing percentage & Breast muscle & Wing & Drumstick & Thigh \\
\hline \multicolumn{6}{|l|}{$c G H$} \\
\hline $\mathrm{AA}(\mathrm{n}=2)$ & 70.9 & 30.0 & 12.8 & 16.1 & 16.5 \\
\hline $\mathrm{AG}(\mathrm{n}=11)$ & 69.3 & 30.2 & 12.4 & 15.9 & 17.0 \\
\hline $\mathrm{GG}(\mathrm{n}=19)$ & 70.7 & 31.1 & 12.1 & 15.4 & 16.8 \\
\hline SEM & 1.0 & 0.8 & 0.4 & 0.5 & 0.6 \\
\hline \multicolumn{6}{|l|}{$I G F-I$} \\
\hline $\mathrm{AA}(\mathrm{n}=8)$ & 70.4 & 31.4 & 12.2 & 15.5 & 16.7 \\
\hline $\mathrm{AC}(\mathrm{n}=21)$ & 70.6 & 30.9 & 12.1 & 15.7 & 17.1 \\
\hline $\mathrm{CC}(\mathrm{n}=3)$ & 70.0 & 29.1 & 13.1 & 16.2 & 16.4 \\
\hline SEM & 1.0 & 0.8 & 0.4 & 0.5 & 0.6 \\
\hline
\end{tabular}

Dressing percentage: the percentage of carcass weight without visceral organ, head, neck, and shanks, calculated on live weight. The percentage of breast muscle, wing, drumstick, and thigh calculated on carcass weight without visceral organs, head, neck, and shanks. $c G H$, chicken growth hormone gene; SEM, standard error of the mean; $I G F$-I, insulin-like growth factor-I gene.

shown in Table 9. There was only tentative association within the four Thai broilers between the $c G H$ and dressing percentage. A previous study revealed that the AA homozygote significantly differed from the GG homozygote in varied carcass traits in a F2 reciprocal cross between the WRR and X Chinese chicken breeds (Nie et al., 2005).

Similarly, in $I G F-I$ gene polymorphism, there was no significant association with any carcass traits. Nevertheless, tentative associations with the breast and wing percentages were found $(\mathrm{p}<0.15)$. Previous study of the same mutation of $I G F-I$ in Thai synthetic chicken lines reported that a significant association of $I G F-I$ was found in only dressing and pectoralis major weight percentages in a single line (Promwatee et al., 2013). Otherwise, the same region of $I G F-I$ within our study revealed that there were significant associations with all observed carcass traits, in $\mathrm{F}_{2}$ Leghorn and Fayoumi cross chickens; at eight weeks of age (Zhou et al., 2005). The opposite effect seen in our study may be the result of chicken samples having been selected at different ages and of different genetic backgrounds.

\section{CONCLUSION}

This study found some significant effects of $c G H$ and $I G F-I$ SNP associated with chicken growth traits. However, the effects, though significant, could not generally be used across breeds. The selected $c G H$ genotypes AG or GG, suggest breeding KM female with male PS chickens, in order to create the $\mathrm{PS} \times \mathrm{KM}$ hybrid, produces a better growth performance and has a greater potential to develop into Thai broilers. The IGF-I gene polymorphisms did not suggest a similar potential, as the genotype effects were unclear. In summary, the $c G H$ gene polymorphisms may be used as genetic markers for improving growth traits in breeding programs for commercial hybrid chickens.

\section{CONFLICT OF INTEREST}

We certify that there is no conflict of interest with any financial organization regarding the material discussed in the manuscript.

\section{ACKNOWLEDGMENTS}

The authors gratefully acknowledge the Research and Development Network Center for Animal Breeding (Native Chicken), Khon Kaen University for help in managing chickens and collecting data. The authors are most grateful to Department of Animal breeding and Genetics, Institute of Animal Science for Southern, Vietnam and the Vietnam Ministry of Education and Training, and Vietnam Ministry of Agriculture and Rural Development for granting the Ms. C. scholarship and for the research funding. The authors wish to acknowledge Animal Genomic Laboratory, Faculty of Agriculture for providing research facilities. This work was also supported by Higher Education Research Promotion and National Research University Project of Thailand, and the Office of the Higher Education Commission, through the Food and Functional Food Research Cluster of Khon Kaen University.

\section{REFERENCES}

Amills, M., N. Jimenez, D. Villalba, M. Tor, E. Molina, D. Cubilo, C. Marcos, A. Francesch, A. Sanchez, and J. Estany. 2003. Identification of three single nucleotide polymorphisms in the chicken insulin-like growth factor 1 and 2 genes and their associations with growth and feeding traits. Poult. Sci. 82:1485-1493.

Apa, R., A. Lanzone, F. Miceli, M. Mastrandrea, A. Caruso, S. Mancuso, and R. Canipari. 1994. Growth hormone induces in vitro maturation of follicle-and cumulus-enclosed rat oocytes. Mol. Cell. Endocrinol. 106:207-212.

Ballard, F. J., R. J. Johnson, P. C. Owens, G. L. Francis, F. M. 
Upton, J. P. McMurtry, and J. C. Wallace. 1990. Chicken insulin-like growth factor-I: Amino acid sequence, radioimmunoassay, and plasma levels between strains and during growth. Gen. Comp. Endocrinol. 79:459-468.

Beccavin, C., B. Chevalier, L. Cogburn, J. Simon, and M. Duclos. 2001. Insulin-like growth factors and body growth in chickens divergently selected for high or low growth rate. J. Endocrinol. 168:297-306

Boschiero, C., E. C. Jorge, K. Ninov, K. Nones, M. F. do Rosário, L. L. Coutinho, M. C. Ledur, D. W. Burt, and A. S. A. Moura. 2013. Association of IGF1 and KDM5A polymorphisms with performance, fatness and carcass traits in chickens. J. Appl. Genet. 54:103-112.

Byatt, J. C., N. R. Staten, W. J. Salsgiver, J. G. Kostelc, and R. J. Collier. 1993. Stimulation of food intake and weight gain in mature female rats by bovine prolactin and bovine growth hormone. Am. J. Physiol. 264:E986-E992.

Denley, A., L. J. Cosgrove, G. W. Booker, J. C. Wallace, and B. E. Forbes. 2005. Molecular interactions of the IGF system. Cytokine Growth Factor Rev. 16:421-439.

Falconer, D. S. and T. F. C. Mackay. 2001. Introducción a la genética cuantitativa. Editorial Acribia, Zaragoza, Spain.

Feng, X. P., U. Kuhnlein, S. E. Aggrey, J. S. Gavora, and D. Zadworny. 1997. Trait association of genetic markers in the growth hormone and the growth hormone receptor gene in a White Leghorn strain. Poult. Sci. 76:1770-1775.

Goodwin, W., A. Linacre, and S. Hadi. 2007. An introduction to forensic genetics. John Wiley \& Sons, Chichester, England.

Hrabia, A., H. E. Paczoska-Eliasiewicz, L. R. Berghman, S. Harvey, and J. Rząsa. 2008. Expression and localization of growth hormone and its receptors in the chicken ovary during sexual maturation. Cell Tissue Res. 332:317-328.

Jaturasitha, S., T. Srikanchai, M. Kreuzer, and M. Wicke. 2008. Differences in carcass and meat characteristics between chicken indigenous to northern Thailand (Black-boned and Thai native) and imported extensive breeds (Bresse and Rhode Island Red). Poult. Sci. 87:160-169.

Kansaku, N., G. Hiyama, T. Sasanami, and D. Zadworny. 2008. Prolactin and growth hormone in birds: Protein structure, gene structure and genetic variation. J. Poult. Sci. 45:1-6.

Kaya, M. and M. A. Yıldiz. 2008. Genetic diversity among Turkish native chickens, Denizli and Gerze, estimated by microsatellite markers. Biochem. Genet. 46:480-491.

Kita, K. and J. Okumura. 2001. Chicken insulin-like growth factor-I stimulates protein synthesis of chicken embryo myoblasts cultured in serum-free medium. Asian Australas. J. Anim. Sci. 14:17-20.

Mehdi, A. and F. A. Reza. 2012. Single nucleotide Polymorphisms in intron 1 of growth hormone gene and it's association with economic important traits in Iranian Fars native fowl. Ann. Biol. Res. 3:4028-4032.
Mu'in, M. and S. Lumatauw. 2013. Identification of MspI polymorphism in the forth intron of chicken growth hormone gene and their associations with growth traits in Indonesia native chickens. Anim. Prod. 15:1-7.

Nie, Q., B. Sun, D. Zhang, C. Luo, N. A. Ishag, M. Lei, G. Yang, and X. Zhang. 2005. High diversity of the chicken growth hormone gene and effects on growth and carcass traits. J. Hered. 96:698-703.

Piper, M. M. and T. E. Porter. 1997. Responsiveness of chicken embryonic somatotropes to somatostatin (SRIF) and IGF-I. J. Endocrinol. 154:303-310.

Promwatee, N., B. Laopaiboon, T. Vongpralub, Y. Phasuk, S. Kunhareang, W. Boonkum, and M. Duangjinda. 2013. Insulinlike growth factor I gene polymorphism associated with growth and carcass traits in Thai synthetic chickens. Genet. Mol. Res. 12:4332-4341.

Rousseau, K. and S. Dufour. 2007. Comparative aspects of GH and metabolic regulation in lower vertebrates. Neuroendocrinology 86:165-174.

Scanes, C. G. 2009. Perspectives on the endocrinology of poultry growth and metabolism. Gen. Comp. Endocrinol. 163:24-32.

Spencer, G. S., J. Buyse, E. Decuypere, and G. Rahimi. 1997. Physiological inhibition of growth hormone secretion by both insulin-like growth factors-I and-II in chickens. Br. Poult. Sci. 38:429-431.

Vasilatos-Younken, R., Y. Zhou, X. Wang, J. P. McMurtry, R. W. Rosebrough, E. Decuypere, N. Buys, V. M. Darras, S. Van Der Geyten, and F. Tomas. 2000. Altered chicken thyroid hormone metabolism with chronic GH enhancement in vivo: consequences for skeletal muscle growth. J. Endocrinol. 166:609-620

Wattanachant, S., S. Benjakul, and D. A. Ledward. 2004. Composition, color, and texture of Thai indigenous and broiler chicken muscles. Poult. Sci. 83:123-128.

Yan, B., X. Deng, Q. Fei, X. Hu, C. Wu, and N. Li. 2003. Association between single nucleotide polymorphisms of the chicken growth hormone gene and chicken growth and carcass traits. Sci. Bull. Sin. 48:1304-1307.

Zhang, C., W. Zhang, H. Luo, W. Yue, M. Gao, and Z. Jia. 2008. A new single nucleotide polymorphism in the IGF-I gene and its association with growth traits in the Nanjiang Huang goat. Asian Australas. J. Anim. Sci. 21:1073-1079.

Zhou, H., A. D. Mitchell, J. P. McMurtry, C. M. Ashwell, and S. J. Lamont. 2005. Insulin-like growth factor-I gene polymorphism associations with growth, body composition, skeleton integrity, and metabolic traits in chickens. Poult. Sci. 84:212-219. 